\title{
COLD WAR II?: SECURITY DILEMMA SENSIBILITY IN RESPONDING TO PUTIN'S ADVENTURE IN UKRAINE
}

\author{
Er-Win Tan
}

\begin{abstract}
Moscow's intervention in Ukraine since early 2014 marks a dangerous development in Russian foreign policy that has potentially significant implications for international security. Russia's actions in Crimea and eastern Ukraine are in direct violation of clearly defined norms of international law. In proclaiming a right to arbitrarily intervene overseas to safeguard the rights of ethnic Russians overseas, Putin's aggressive new foreign policy sets a dangerous precedent for other countries that may wish to use force to suit their own geostrategic aspirations. Furthermore, given the security fears in Eastern Europe that have arisen from Putin's involvement in Ukraine, it is also necessary for the Transatlantic Community to adopt a firm response in underlining international opposition to Russia's actions. Yet, it is necessary to avoid viewing Putin's Russia as an imminent threat to the security of Eastern Europe that has to be confronted. An analysis of the current situation in Eastern Europe using the theoretical framework of the security dilemma suggests that confronting Russia at this stage may cause an already serious situation to escalate further. Rather, it is necessary for the Transatlantic Community to respond to Russia's involvement in Ukraine with a mixture of firmness and strategic restraint.
\end{abstract}

Keywords: Ukraine, Russia, Putin, Security Dilemma

\section{INTRODUCTION}

The present moment finds Eastern Europe facing what it arguably its worst crisis since the end of the Cold War as a result of Russian President Vladimir Putin's apparent ambition to bring about a return to the great power status that Moscow had lost with the collapse of the Union of Soviet Socialist Republics (USSR) in 1991. Although 
Moscow has denied involvement in the recent unrest in Crimea as well as the ongoing, escalating tensions in eastern Ukraine, such denial is at best disingenuous in veiling external instigation of violence that is clearly aimed at bringing parts of Ukraine into Russia's traditional sphere of influence. Russia has been quick to hand out its citizenship to its supporters in South Ossetia and Abkhazia in Georgia, as well as in Crimea in the Ukraine, thereby enabling Moscow to proclaim its right to intervene to protect its new citizens. ${ }^{1}$ There is little dispute that the takeover of the Crimean Peninsula was carried out by Russian troops via Russia's military bases in the Crimea, or that Russianorganized operatives are behind the ongoing violence in Ukraine's eastern regions. ${ }^{2}$

In so doing, Russia's actions pose difficult questions for the security of Europe. The borders of both the former Soviet Union as well as the Czarist Russian Empire encompass not only Ukraine, but also other now-independent nation-states in Eastern Europe that are members of the North Atlantic Treaty Organization (NATO) - the primary collective security organization of the Transatlantic Community $^{3}$, itself formed in 1949 to guard against the threat of Soviet expansion during the early years of the Cold War. Further underscoring the fears of Eastern Europe that have arisen as a result of Russia's increasingly assertive posture under Putin are the demographic and historical characteristics of many of these East European countries. Many of the latter, like Ukraine, have large populations of ethnic Russians within their borders, and much of Eastern Europe had suffered under the domination of communist regimes imposed by Stalin at the end of the Second World War.

I propose to outline my analysis by beginning with a brief review of recent scholarship on security dilemma theory. I then follow this theoretical backdrop with analysis of the intentions behind Putin's increasingly assertive foreign policy. This reflects Russian dissatisfaction with the political status quo that marked the period between the collapse of the Soviet Union in 1991, and Putin's first presidency that began in 2000. In this regard, the Russian intervention in Ukraine is a clear attempt to regain the great power status that had been lost amidst the ignobility of the post-Cold War period. Even whilst acknowledging that Putin's intervention in Ukraine has been driven by a desire to regain great power status, rather than a conscious 
decision to return to the confrontation of the Cold War, however, it is nonetheless necessary for the US and NATO to adopt a posture of diplomatic and security firmness against any further Russian transgressions into Eastern Europe. This is reflected first with reference to key elements of international law that clearly marks Russia's actions as a violation of international norms of conduct. Secondly, given that Putin's intervention in Ukraine has the potential to undermine regional security in Eastern Europe (with potential global implications), it is necessary for the US to affirm the credibility of the Transatlantic Alliance. This article will then conclude with an examination of how signals of diplomatic and military firmness can be adopted without causing unnecessary escalation of an already tense situation.

\section{THE SECURITY DILEMMA IN THE $21^{\text {ST }}$ CENTURY}

In the mainstream academic literature, the security dilemma is defined as a situation in which the security of a country can only be achieved at the expense of its rivals. Such a scenario is illustrated in the cycle of arms racing, in which one state acquires more armaments to defend itself against external security threats. In so doing, however, a rival interprets such arms acquisitions as a sign that the first state is arming itself to undertake military expansion for offensive purposes. The rival state accordingly arms itself as well to defend against such an outcome. Yet, because neither side acknowledges the other's fear, both sides assume that their rival is arming out of hostile intentions, thereby leading to a vicious circle of escalating hostility.

More recent literature, however, takes a different interpretation of the security dilemma. In their 2008 book, The Security Dilemma: Fear Cooperation and Trust in World Politics, Booth and Wheeler redefined the phenomenon as the two-level strategic predicament that policymakers have to address in the formulation of national security strategy, namely, the dilemma of interpretation, and the dilemma of response. ${ }^{4}$ Within this typology, the dilemma of interpretation reflects the difficult situation faced by policymakers in attempting to determine if the security posture of a rival state is driven by hostile intentions (e.g. for territorial expansion or wars of conquest) or defensive ones (e.g. to enhance security). ${ }^{5}$ When policymakers resolving a dilemma of interpretation in the belief that the rival state has hostile intentions, they thus believe that they face a 'strategic challenge'. ${ }^{6}$ Under such 
circumstances, they have to address their resulting dilemma of response: should they adopt a posture of firmness (e.g. sanctions, highprofile military exercises) to deter the perceived aggressor from further belligerence? Or should they adopt a posture of restraint (e.g. seek a negotiated resolution) in order to bring about a peaceful outcome?

Both courses of action carry elements of risk - a posture of deterrence has the potential to arouse the security fears of the rival state even further, thereby causing existing tensions to escalate into a vicious circle and preventing a peaceful resolution of the crisis (as reflected in how the July Crisis escalated into the First World War). Conversely, adoption of a posture based on restraint may have the effect of undermining the credibility of deterrence and encouraging the aggressor state to believe that further belligerence will go unopposed, thereby whetting the appetite for conquest (as exemplified by Hitler's belief after Anglo-French appeasement during Sudetenland Crisis of 1938 that the Nazi invasion of Poland would be met by acquiescence in London and Paris.)

Before concluding this section on defining the security dilemma, it would also be necessary to acknowledge a further contribution to literature on the security dilemma from Booth and Wheeler. They also introduce the term 'security dilemma sensibility' to refer to the ability of ability of policymakers to ascertain the possibility that another states' apparently aggressive conduct may be the result of fear, rather than malice. Particularly crucial in security dilemma sensibility is the ability of policymakers to realize that their own actions in the past may have contributed to their rivals' fear - in short, acknowledging the mutually constitutive nature of the security dilemma. ${ }^{7}$ Under such circumstances, security dilemma sensibility requires policymakers to enter into the fears of their rival, implement Confidence and Security Building Measures (CSBMs) that address their rivals' fears ${ }^{8}$, even whilst assuaging the security fears of their allies. ${ }^{9}$

\section{RUSSIA'S GREAT POWER RESURGENCE}

Russia's intervention in Crimea and eastern Ukraine should not be seen as coming out of the blue. Russia has historically regarded Eastern Europe - in particular, the former Soviet Republics of Belarus, Latvia, Lithuania, Estonia and Ukraine - as its sphere of influence. During the 
early 1990s, Andrey Kozyrev, Russia's first post-Communist Foreign Minister, had coined the term 'the near abroad', to refer to regions beyond Russia's post-1991 borders, over which Moscow held major interests. ${ }^{10}$

The strategic importance of the Near Abroad is reflected by the historical legacy of invading armies that marched eastward through this region in 1812, 1914 and $1941 .{ }^{11}$ Given that the extent of this strategic depth was not sufficient in preventing Moscow from coming under direct attack by the armies of Napoleon and Hitler, it is little wonder that successive generations of Russian and Soviet leaders have viewed Eastern Europe as the crucial buffer zone in providing sufficient strategic depth for the security of Moscow. Such fears were thus reflected in Stalin's imposition of a series of Soviet puppet regimes in Eastern Europe following the end of the Second World War. Further underscoring Russian interests in the former Soviet republics in Eastern Europe is the existence of sizeable communities of ethnic Russian stock who, although privileged during Soviet times, have since faced discrimination by the post-Communist governments that administer the former Soviet republics.

Under such circumstances, the extent of post-Soviet Russia's impotence was reflected by trends that underscored the downfall of Moscow's great power status following the breakup of the USSR. Within Russia, the 'shock therapy' approach to economic reform that had been undertaken by Gorbachev and Yeltsin had resulted widespread economic chaos, with rampant inflation, structural unemployment and severe 'brain drain' as Russian intelligentsia emigrated in search of a better life overseas. Furthermore, the extent to which the once-prestigious Soviet military had lost its operational edge was highlighted by the prolonged stalemate during Moscow's attempt to suppress the Chechen separatist movement in 1994-1995, and the loss of the submarine Kursk in 2000 with all hands aboard.

More humiliating for Russia, however, was the lack of sensitivity with which the Transatlantic Community formulated diplomatic and security policy in post-Soviet Europe. In light of the many overland invasions of Russia that were staged from the frontiers of Eastern Europe, NATO's lack of sensitivity to Russian interests during the 1990s underscored Moscow's impotence to a humiliating extent, 
whilst reinforcing Moscow's perception of NATO as being arrogant and insensitive in failing to accommodate Moscow's interests in this region. The period since 1991 has seen NATO expansion of its membership to include the USSR's former Warsaw Pact satellite states, notably Hungary, Czechoslovakia, Poland, Lithuania, Latvia and Estonia. ${ }^{12}$ Ascension to NATO membership of the latter four countries was particularly galling for Russian interests, as it marked NATO's expansion to the borders of Russia itself. ${ }^{13}$ Moreover, in 1999, NATO had undertaken a devastating air campaign against Russia's clientstate, Serbia in a bid to terminate the Serbian campaign of "ethnic cleansing' in Kosovo.

Of particular alarm to Russia was the Bush Administration's installation of Theatre Missile Defence (TMD) systems in Poland and the Czech Republic. Although purported as a non-offensive measure that safeguarded European security against the threat of Iran's alleged nuclear missile ambitions, Russia has had reason to fear US cooperation with Europe in the development of an operational TMD. As early as the 1980s, the USSR had feared that Reagan's undertaking of the 'Star Wars' missile defense program (and forerunner of TMD) neutralized the Soviet nuclear arsenal, thereby rendering Moscow vulnerable to nuclear as well as conventional coercion by the US and NATO. Although Reagan had discontinued 'Star Wars' in response to Gorbachev's peace feelers during the 1980s, the Bush Administration's undertaking of TMD, alongside US unilateralism the War on Terror, was evidence of US ambitions at seeking global hegemony. Such ascendancy of US power, whilst not directly aimed at Russia, nonetheless had the effect of convincing Russia that it was to be relegated to a second-rate power at best, and one whose ability to affirm the security of its Western borders would be beyond its control.

Set against this backdrop, Putin's agenda in seeking to restore Russia's prestige as a great power is understandable, given his background as a former officer in the Soviet-era KGB. This was further evident during Putin's first Presidency (2000-2008), with continued crackdowns on the Chechen separatists and affirmation that Chechnya remained under Russian sovereignty. ${ }^{14}$ Furthermore, as Prime Minister from 2008-2012, the Russian media highlighted photographs of him physically fit, bare-chested and on horse-back, reflecting the traditional Russian image of a 'strong man' (literally as well as metaphorically) 
capable of leading the country out of the chaos of the 1990s as well as the ongoing global economic crisis since 2008. ${ }^{15}$ Moreover, during the Orange Revolution in Ukraine in 2004 that saw the electoral rejection of the pro-Moscow Viktor Yanukovych's bid for Presidency, Putin apparently saw US and EU support for Ukraine's fledgling democracy as a sign that the Transatlantic Community sought to encircle Russia. ${ }^{16}$

Seen in this light, whilst Putin's intervention in Ukraine has been analogically compared by commentators to Hitler's occupation of the Sudetenland in 1938 (and hence evidence of Russian ambitions of world domination), ${ }^{17}$ it may instead be argued that Moscow's increasingly assertive foreign policy posture underscores Russia's perception that the Transatlantic Community's eastward expansion marks a strategic challenge to Russian interests. Such a backdrop has thus shaped Putin's ambition in returning Russia to its rightful place as a great power in international relations. Prior to the intervention in Ukraine, Putin clearly acknowledged that bringing Russia into a 'Cold War'-like collision course with the Transatlantic Community was not in Moscow's interests. Putin instead redirected Russia's focus on exploiting its vast reserves of oil and natural gas, thereby transforming the economically troubled Russia that Putin inherited, into a key supplier of Western Europe's energy sector. Furthermore, rather than compete with the Transatlantic Community for influence in Europe or the Middle East, Russia consolidated its position in Central Asia, thereby maintaining influence over the former Soviet Republics and developing a more cooperative relationship with China via the Shanghai Cooperation Organisation.

The increasing shift towards an assertive Russian foreign policy was apparent as early as 2008, when Putin, as Prime Minister, worked alongside President Dmitri Medvedev in intervening against Georgia during the South Ossetian Conflict. As another former Soviet republic, and one that bordered major energy sources within Russia, Georgia too was seen by Moscow as part of its traditional sphere of influence. In attempting to maintain territorial integrity of the country, Georgian President Mikheil Saakashvili's coercive clampdown on South Ossetian separatists had the effect of provoking full Russian intervention. ${ }^{18}$ 
Russia's ongoing intervention in Ukraine has taken a similar pattern. Having won the 2010 bid for Presidency, Yanukovych's administration was marked by attempts to align the country away from the EU, towards the embrace of Russia (and hence in line with Russian aspirations to maintain a friendly buffer zone on its western frontiers). At the same time, however, in blocking the Ukrainian peoples' aspirations for closer relations with the EU (and hence the prospect for improved standards of living), Yanukovych's pro-Russian policies had the effect of alienating his administration from the large sections of society, in particular in western Ukraine. Combined with allegations of widespread corruption in Yanokoych's cabinet, the resulting Euromaiden protests in February 2014 culminated in the toppling of Yanokovych from power. Although these developments were initially welcomed by EU circles as vindication of the expansion of democracy in Eastern Europe, it was evident that Putin saw these developments as further EU encroachment onto Russia's 'Near Abroad', hence triggering the interventions in Crimea as well as eastern Ukraine. Such trends point to what commentators have referred to as the 'Putin Doctrine', outlining Russia's claim to the right to intervene anywhere in the world to protect the rights of ethnic Russians abroad. ${ }^{19}$

Yet, even whilst acknowledging that Putin has reason to view the Transatlantic Community's influence in Ukraine as a strategic challenge that infringes on Russian geostrategic interests, Putin's own intervention in Ukraine marks a converse security dilemma for NATO. If Russia is prepared to engage in the unilateral and arbitrary use of force in the redrawing its borders to its own satisfaction, it sets a dangerous precedent for international relations as well as the security of Eastern Europe, given that other states in the latter region also have significant communities of ethnic Russia stock. Moreover, the past history of Moscow's domination of Eastern Europe under the Tsarist and Communist eras, including the use of harsh measures to suppress local nationalist sentiments, remains a painful memory for many East Europeans. A resurgent nationalist Russia with an aggressive foreign policy should thus be regarded as a potential threat to the security, sovereignty and territorial integrity of the states in Eastern Europe. Such trends underscore the need for diplomatic firmness on the part of the Transatlantic Community in affirming the credibility of deterrence against Russian claims to do as it pleases within Eastern Europe. There are two grounds to underline the necessity of the Transatlantic 
Community in adopting a firm diplomatic and security response to Putin's actions in Ukraine.

\section{THE CASE FOR FIRMNESS: INTERNATIONAL LAW}

Underpinning key norms of state conduct in international relations is the role of international law, and herein, several key aspects of the latter undermine the legitimacy of Putin's intervention in Crimea and the Ukraine. Foremost amongst these is the generally accepted norm against the use of force in international relations. This was evident as early as the 1928 Kellogg-Briand Pact, which bound signatory-states not to use force to resolve "disputes or conflicts of whatever nature or of whatever origin they may be, which may arise among them." ${ }^{20}$ This was further affirmed following the outbreak of war between Japan and China 1931 over the status of Manchuria. Japan's initiation of armed force was condemned by the international community, with US President Herbert Hoover and Secretary of State Henry Stimson refusing to de jure acceptance of Japan's revision of its territorial demarcation in Manchuria. In affirming that the Japanese invasion of Manchuria constituted ex injuria jus non oritur (Latin: 'law does not arise from injustice'), the Hoover-Stimson doctrine marked an emerging rejection of changes in territory resulting from the use of force. ${ }^{21}$

Further codifying the emerging norm against the use of force in international relations was the central role of the Charter of the United Nations as a yardstick in marking membership in the post-1945 international community. Of particular note is Article 2(4) of the UN Charter, affirming that "(A)11 Members shall refrain in their international relations from the threat or use of force against the territorial integrity or political independence of any state." Furthermore, it is notable that in the decades since 1945, the use of force has generally been couched in such euphemistic and ambiguous terms that have sought to move away from official government mentions of the word 'war'. In other words, even if governments' formulation of national security strategy remains rooted in realpolitik, there is also widespread acceptance of an opinion juris - that is, the acceptance by states that there are clear norms of conduct that should be followed as part of the consensus that underpins international law - that frowns on the use of force in international relations. Ratification of the UN Charter is considered 
a defining legal instrument in legitimizing membership in the world body. As such, Russia's instigation of strife in Crimea following the Euromaiden protests, and again in cities in eastern Ukraine, marks a clear and illegal violation of Ukrainian sovereignty.

Further reflecting the illegitimacy of Russia's involvement in Ukraine are the aspects of international law that concern state succession. Putin had justified intervention in Crimea on the basis that the peninsula had been ceded to the Ukrainian Socialist Republic by Khrushchev at a time when both Ukraine and Russia were part of the USSR. Given that Russian interest in the warm-water ports of the Crimean Peninsula as an area of core interest dates back to Tsarist times, the ceding of the peninsula has been regarded by the majority of Russians as a historical mistake. ${ }^{22}$ Yet, to use this as a starting point to justify Russia's intervention in Crimea marks a dangerous challenge to international law in posing a potential Pandora's Box of ambiguous territorial claims that have been accumulated over history.

Putin's rejection of Khrushchev's ceding of Crimea to Ukraine notwithstanding, there are already clear international norms concerning the territorial status of disputed territories after the breakup of a state, notably the 1978 Vienna Convention on Succession of States in respect of Treaties. Article 24 of the Vienna Convention is particularly clear on this point, affirming that

1. A bilateral treaty which at the date of a succession of States was in force in respect of the territory to which the succession of States relates is considered as being in force between a newly independent State and the other State party when:

a. they expressly so agree; or

b. by reason of their conduct they are to be considered as having so agreed.

2. A treaty considered as being in force under paragraph 1 applies in the relations between the newly independent State and the other State party from the date of the succession of States, unless a different intention appears from their agreement or is otherwise established. ${ }^{23}$ 
This is made further explicit by Article 26 of the Vienna Convention, declaring that:

1. When under article 24 a treaty is considered as being in force between a newly independent State and the other State party, the treaty:

a. does not cease to be in force between them by reason only of the fact that it has subsequently been terminated as between the predecessor State and the other State party;

b. is not suspended in operation as between them by reason only of the fact that it has subsequently been suspended in operation as between the predecessor State and the other State party;

c. is not amended as between them by reason only of the fact that it has subsequently been amended as between the predecessor State and the other State party. ${ }^{24}$

In other words, however Putin wishes to define the legal status of Russia as a successor state to the USSR, and the succession of post-1991 Ukraine to the territories administered by the Ukrainian Socialist Republic, the result is the same - that international treaty law recognizes post-Soviet Ukraine's inheriting of the Crimean peninsula.

Further supporting the international legal status of Crimea as part of Ukraine is the legal precedence established by events prior to Putin's Presidency. As early as December 1994, Russia, along with the UK and US, had signed the Budapest Memorandum on Security Assurances as part of the process of seeking Ukraine's dismantlement of the nuclear weapons that Kiev had inherited following the collapse of the USSR. Of particular interest was that, in signing the Budapest Memorandum, Moscow had accepted the following obligations to Ukraine:

1. commitment to Ukraine, in accordance with the principles of the Final Act of the Conference on Security and Cooperation in Europe, to respect the independence and sovereignty and the existing borders of Ukraine; 
2. obligation to refrain from the threat or use of force against the territorial integrity or political independence of Ukraine;

3. to refrain from economic coercion designed to subordinate to their own interest the exercise by Ukraine of the rights inherent in its sovereignty and thus to secure advantages of any kind. ${ }^{25}$

In other words, regardless of the circumstances that surrounded Khrushchev's ceding of Crimea to the Ukraine, Russia, as the successor state to the USSR, is bound by international treaty law to acknowledge that the Crimean Peninsula is a territory that falls under the sovereignty of Ukraine. Whilst the implications of international law over the status of Crimea may be politically inconvenient for Putin's image of a reinvigorated Russia, it would be an extremely dangerous precedent if any state - in particular a powerful, influential, permanent member of the United Nations Security Council (UNSC) - to unilaterally reject international law to suit its own interests at the expense of international stability and security. In setting such a dangerous precedence, it opens international law to abuse by other states willing to use force to redraw international territorial boundaries to suit their geostrategic and historic aspirations.

\section{THE CASE FOR FIRMNESS: INTERNATIONAL SECURITY}

Whilst a realist approach to international relations is based on the notion that 'might is right', international acquiescence to Russia's involvement in Ukraine runs the risk of extremely dangerous developments in international relations. A failure to communicate diplomatic firmness over Russia's intervention in the Ukraine would signal the inability of the international community in opposing the illegal use of force in international relations and thus weaken the coherence of the international norm against war. Under such circumstances, other states with territorial ambitions of their own can point to the Transatlantic Community's weak-willed response to Russia's involvement in Ukraine as a legal precedent that would obviate international condemnation. In undermining the basis for international law against the use of force, such a scenario would bear a disturbing resemblance to Hobbes' characterization of the state of nature as one where life is 'solitary, poor, nasty, brutish, and short' - 
in other words, a world order in which states have to compete against one another in safeguarding their security. If the history of conflict in preceding centuries is to be reflected upon, a world of renewed great power rivalry would be a very grim prospect for the future of the international community.

The seriousness of such a scenario is highlighted by the potential geostrategic and historical repercussions for the security of the nations of Eastern Europe. Given the extent to which the political borders of the region have moved back and forth, several East European countries have sizeable communities of ethnic Russian stock. In 2008, Russia had intervened in Georgia over the 1.8 percent of the Georgian population of Russian stock; Ukraine, scene of the current Russian involvement, counts 17.3 percent of its population as hailing from Russian descent. Under such circumstances, other East European and Central Asian former Soviet Republics have reason to fear that they too might be next in line for the application of the 'Putin Doctrine'. As indicated in Map 1, more than 20 percent of the populations of Estonia, Latvia and Kazakhstan are also of the Russian stock. In this regard, it should be noted that even the comparatively liberal General Secretary, Mikhail Gorbachev, went to great lengths to suppress the independence activists of the three Baltic states (Estonia, Latvia and Lithuania), suggesting that, even among Russian liberals, the continuation of Moscow's influence in the Baltic trumped rapprochement with the US. ${ }^{26}$

A weak-willed response to the situation in Ukraine may result in the perception (both in Moscow as well as among the other East European states) that there is little resolve in the European Union or NATO to stop further actions aimed at restoring the prestige that Moscow had enjoyed during the days of the Soviet Union. This in turn bears serious consequences for security in Europe for two reasons. First, a weak-willed EU and NATO response is likely to convince Putin that the Transatlantic Community lacks resolve in opposing Putin's ambitions to restore to Moscow the power and prestige that had been enjoyed during the era of the Soviet Union. Such a scenario may embolden Putin into further transgressions into Eastern Europe in the application of the 'Putin Doctrine', or as part of the wider strategy of restoring Russian great power status. Either way, if a failure to communicate firmness against Russian involvement in Ukraine leads to further Russian transgressions in the Baltic States at a later date, 
the prospective cost of such a confrontation would be extremely high for both NATO and Russia. Latvia, Lithuania and Estonia are NATO members, and a NATO-Russian confrontation in the Baltics would mean either outright war, or either side being forced into a humiliating retreat (thereby sowing the seeds for yet another confrontation further down the line). Such scenarios would not bode well for the long-term security and stability of Eastern Europe.

Second, and conversely, the prospect of an aggressive, expansionist Moscow seeking a revival of the Soviet/Russian empire is one that significantly arouses the fear of virtually every country in Eastern and Central Europe. The historical legacy of Moscow's past influence in Eastern Europe (in the former Soviet Republics as well as the USSR's Warsaw Pact satellites) is one of deeply-rooted antagonism. Many Ukrainians recall the era known as the Holodomor ('Extermination by Hunger') during the 1930s, when Stalin's imposition of the system of collective farms and confiscations of agricultural output led to the outbreak of a famine that killed millions. ${ }^{27}$ Although the peoples of the Baltic States enjoyed a brief period of independence during the interwar period from 1919 to 1939, Soviet victory during World War Two meant the imposition of totalitarian regimes in the Baltic that crushed nationalist sentiment. The peoples of the former East Germany, the Czech and Slovak Republics, Poland, Hungary, Bulgaria and Romania all suffered during the decades that followed the end of World War Two as a result of the Soviet imposition of harsh, totalitarian regimes. Moreover, aware of their domestic unpopularity, the Soviet-sponsored regimes in Eastern Europe maintained regime security by suppressing civil liberties and nationalist sentiments with brutal secret police forces. Particularly traumatic were the cases of Hungary in 1956 and Czechoslovakia in 1968, which saw outright invasion by the Red Army for not adhering to Soviet ideology. Such a backdrop in turn underscores the aspirations of many East Europeans in seeking closer relations with the EU and NATO, not only to reach the levels of affluence and social progress attained in Western Europe during the second half of the $20^{\text {th }}$ century, but also as a security guarantor in the post-Communist world (it should be noted that both Poland and the Czech Republic were enthusiastic supporters of the Bush Administration's undertaking of the TMD program in Europe). 
Whilst it is true that the mandates of NATO and the EU do not, at present, extend to the security of Ukraine, it is also important to think in terms of the symbolic value of a failure to come to the aid of a small, weak nation facing the prospect of invasion. As noted earlier, the East European states have reason to be fearful for their own security as a result of Putin's adoption of an aggressive new foreign policy. An inability on the part of the Transatlantic Community to communicate firmness against Putin's intervention in Ukraine would indicate that the major powers that provide NATO's muscle - the US, UK, France and Germany - may not be relied on for security against a Russian invasion. Under such circumstances, and taking into account the aforementioned scenario of an emboldened Putin seeking to restore Moscow's influence in the Near Abroad, the former Communist countries of Eastern Europe may instead discount the credibility of the NATO security guarantee, and instead adopt a defense posture based on self-reliance. At the same time, however, given the overwhelming conventional and nuclear superiority enjoyed by Moscow, there is a danger that the states of Eastern Europe, fearing alliance abandonment by NATO, may thus view the development of an independent nuclear arsenal as a strategic equalizer against Russian military strength.

Such an outcome is not implausible; following the breakup of the USSR in 1991, Ukraine (along with Belarus and Kazakhstan) inherited large numbers of the USSR's nuclear warheads, and had sought to maintain the latter as a security safeguard against the prospect of a resurgent Russia. It was only because of the security guarantees that Kiev received from the US, UK and Russia under the Budapest Memorandum in 1994 that the Ukrainian Government agreed to the dismantlement the Soviet-era nuclear warheads on its soil. Had Kiev the benefit of hindsight in 1994 with regards to the current situation posed by Russia's current actions, it is likely that the Budapest Memorandum would have been rejected in favour of an independent Ukrainian nuclear arsenal. ${ }^{28}$

Moreover, historical precedence from Asia further highlights the likelihood of how a small or medium sized country, faced with a direct security threat and a wavering great power ally, may seek an independent nuclear arsenal as its ultimate security guarantee. Following the outbreak of the Korean War in 1950, the US had maintained a military presence on the Korean Peninsula, with the 
implicit understanding that Washington was prepared to use nuclear warheads against another North Korean invasion of the South. Following the quagmire of the Vietnam War, however, in 1969, US President Richard Nixon announced the 'Guam Doctrine', under which Washington would "look to the nation directly threatened to assume the primary responsibility of providing the manpower for its defense." 29 This speech was particularly alarming for ROK President Park Chung Hee, as Nixon withdrew the US $7^{\text {th }}$ Infantry Division constituting half of the US Army's strength on the Korean Peninsula - in 1971, at the same time as Washington accelerated the concurrent US withdrawal from South Vietnam. ${ }^{30}$ Fearing alliance abandonment in the face of North Korea's larger military, President Park attempted the development of an independent South Korean nuclear weapons arsenal. ${ }^{31}$

Seen in this light, the implications of a weak-willed NATO and EU response are significant. A failure to adopt a firm posture against Russia's involvement in Ukraine may arouse fears of alliance abandonment, particularly among the newer members of NATO. Most of the East European countries have civilian nuclear plants as well as chemical production facilities, both of which incorporate dual-use technology that may be converted to military purposes. Whilst the East European states may face technical difficulties in mastering the process necessary to cause a nuclear chain reaction - the basis for an operational nuclear warhead - chemical weapons are easier to develop from scratch, and have thus been referred to by various commentators as 'the poor man's nuclear bomb'.32 Given the moral taboo as well as international treaties that prohibit the development of Weapons of Mass Destruction (WMD), the potential impact of a WMD arms race that may result from East European fears of alliance abandonment by NATO is a scenario of some concern.

\section{CONCLUSION}

These implications thus underline the necessity for the Transatlantic Community to adopt a firm position in opposing Russia's involvement in Ukraine. At the same time, however, it is also necessary, for several reasons, to walk a fine line in adopting a posture of firmness in expressing the international community's disapproval. As noted at 
the beginning of this article, whilst Putin's intervention in Ukraine has been compared by commentators to be analogous to Hitler's occupation of the Sudetenland in 1938, this is based on a simplistic portrayal of history. This is perhaps understandable, given the extent to which policymakers as well as laymen invoke the Second World War as a metaphorical manifestation of how the worst tendencies in human nature affect international politics for the worse. Such an interpretation of history is simplistic, inasmuch as it relies on cliché images of the Nazi regime. Rather, given the extreme nature of the Nazi ideology, it might be more helpful to view the parable of the Hitler's bid for world domination as a historical anomaly, comparable to the campaigns of world conquest undertaken by Julius Caesar or Genghis Khan.

As Thomas Christensen noted, however, comparatively few statesmen are 'Hitlers' intent on world conquest. Rather, Christensen argued that, when states undertake expansion against one another, the majority of such episodes in history have been driven by the security fears of one side or the other, rather than ambitions of conquest. Putin's foreign policy is consistent with this mould of a statesmen, whose intervention in Ukraine appears to be driven not by ambitions of world domination, but of seeking to advance his interpretation of Russian security interests in an uncertain world by regaining the great power prestige that Russia had lost following the collapse of the Soviet Union. Under such circumstances, and recalling how NATO expansion during the 1990s had contributed to the groundswell of Russian nationalism that is supporting Putin's current adventurism in Ukraine, imposition of unnecessarily harsh terms on Moscow in seeking an end to Russia's instigation of the ongoing strife in Ukraine would likely have the effect of forcing Putin into a corner. Under such circumstances the Russian leadership would have to either endure a humiliating retreat on the world stage (thereby breeding long-term Russian resentment over the perceived arrogance of the West), or be forced to lash out by escalating an already tense situation in Eastern Europe.

Moreover, although militarily unprepared for a confrontation with NATO, Russia is in a strong position to turn a confrontation with the Transatlantic Community into a situation that has the potential to undermine the world economy. Having undertaken massive investment and expansion of its oil and energy sector, Russia is in a strong position 
Figure 1: Ethnic Russian population as a percentage of the total population of East European countries ${ }^{33}$

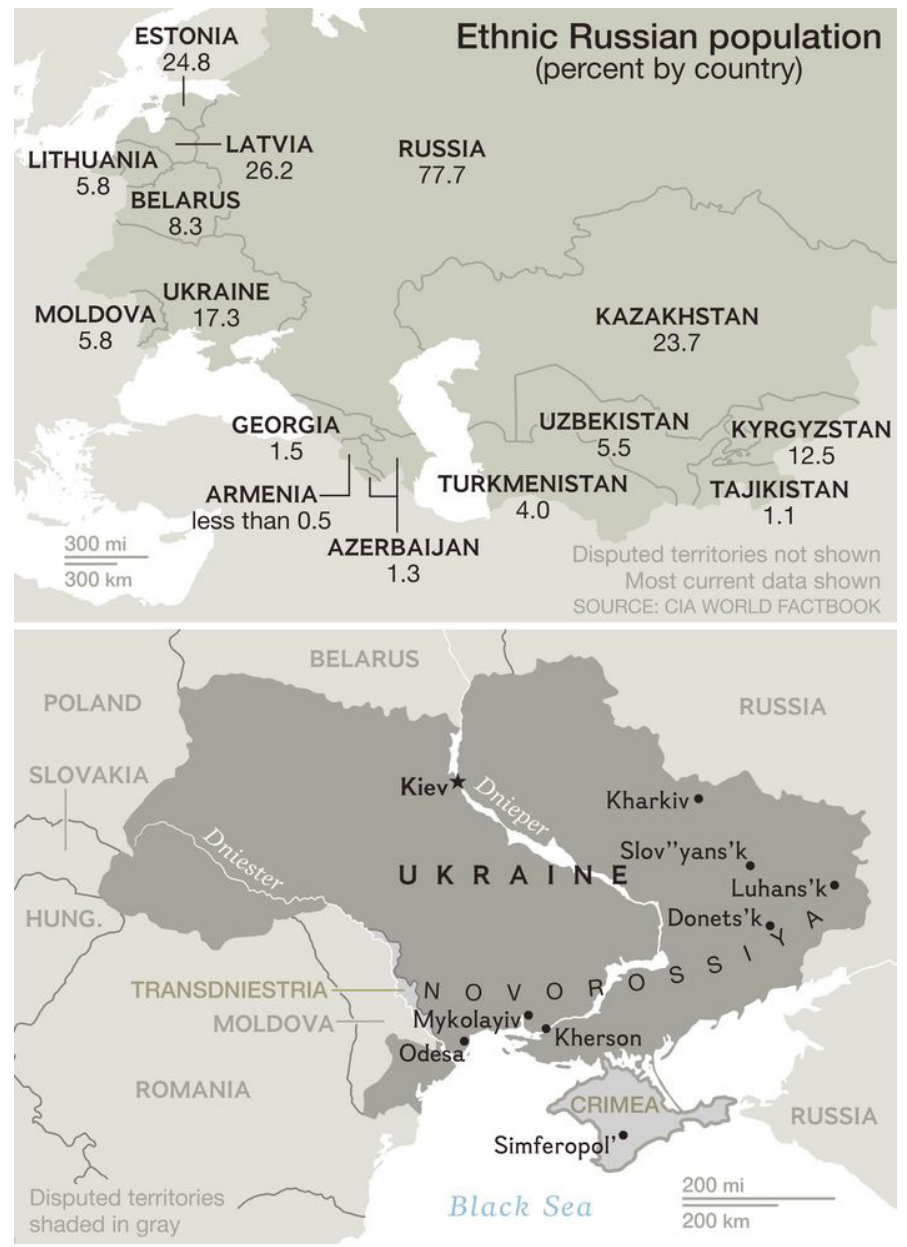

to retaliate against attempts at international sanctions aimed at Moscow by reducing or even terminating the supply of natural gas and oil to Western Europe. Such a scenario, by posing the prospect of global economic chaos amidst international attempts at economic recovery, would make a bad situation worse, possibly causing the existing crisis to escalate beyond the hope of recovery.

Set against this backdrop, a posture of security dilemma sensibility offers the best prospects for exploring the options for a 
peaceful resolution of the current impasse, whilst hedging against any further escalation. Within the current context, security dilemma sensibility requires a combination of firmness and restraint. A position of firmness is necessary in underlining that the international community will not acquiesce to Russia's flagrant violation of international law, whilst affirming the credibility of NATO and assuaging the security fears of other East European states. Such firmness may take the form of increasing the extent of the sanctions already in place, or in the graduated redeployment of US military forces to Europe (the last of the US Army's tanks were withdrawn from Europe in April 2013).

Even whilst communicating firmness, however, it is also necessary to ensure that the Transatlantic Community can offer Putin a face-saving way out of the current impasse. If there is to be a longterm resolution of the differences between Moscow's interests and those of the Transatlantic Community's, it is crucial that an effort is made to address the root causes of the current tensions, including the simmering Russian perception that Moscow's strategic interests in international relations have been marginalized since the end of the Cold War. Such an approach would be difficult, given that a posture of restraint towards Moscow may have the concurrent effect of arousing East European fears that the Transatlantic Community is prepared to sacrifice a portion of East European territory to avoid war with Moscow. Rather, it is necessary for the Transatlantic Community to ensure that any concessions to Russian interests are clearly linked to reciprocal actions on the part of Putin that demonstrate Russian strategic restraint with regards to Eastern Europe.

Such an approach could involve the undertaking of closed-door dialogue between the Transatlantic Community and Russia, enabling a negotiating process that allows give-and-take without publicly making humiliating concessions. In exchange for Russian restraint in Eastern Europe (for instance, a verifiable end to Moscow's instigation of armed militias in Ukraine), reciprocal concessions to Russia may be proffered, such as a graduated lifting of sanctions that have been imposed since April. Over time, an improvement in relations between the Transatlantic Community and Russia may enable an environment conducive for further hedging against further instability. Such measures may include some form of limited autonomy for ethnic Russians in 
Ukraine, conditional on Russian respect for the territorial integrity of the former Soviet Republics.

\section{NOTES}

1 Agnia Grigas, "How Putin carries out power grab," CNN, 2 March 2014, <http://edition.cnn.com/2014/03/02/opinion/grigas-putin-compatriotpolicy-crimea/index.html?hpt=hp_t2>

2 Peter Beaumont, "Russia makes latest high-risk move to keep pieces of its "near abroad' in check," The Guardian, 2 March 2014; and Michael R Gordon, "Russia Displays a New Military Prowess in Ukraine's East," New York Times, 21 April 2014.

3 For the purpose of this manuscript, the term 'Transatlantic Community' refers primarily to members of the NATO alliance and the European Union (EU), as having the member-states whose security and diplomatic interests are most directly affected by the rise of a resurgent Russia. It should be emphasized that the states of the Transatlantic Community include members that are both NATO and the EU (such as Germany and Poland), non-NATO members of the EU (such as Sweden and Finland), European non-EU members of NATO (such as Norway and Iceland), and the North American NATO members (the US and Canada). Finally, it would also be necessary to acknowledge the presence of states which are members of neither organization (such as Switzerland and Liechtenstein); although located in Europe, their geographic distance from Eastern Europe and their overall posture of diplomatic neutrality means that they are less affected by the situation in Ukraine, as compared to members of NATO and the EU.

4 Ken Booth and Nicholas Wheeler, The Security Dilemma: Fear, Cooperation and Trust in World Politics, Basingstoke: Palgrave Macmillan, 2008, pp. 4-5.

5 Ibid., p. 4.

6 Ibid., p. 9.

7 Ibid., p. 7.

8 This concept was initially coined as 'confidence-building measures and certain aspects of security and disarmament' in the Final Act of the 'Conference on Security and Co-operation in Europe' in Helsinki in 1975 (also known as the Helsinki Accords). See "Conference on Security and Cooperation in Europe," Helsinki: Organization for Security and Co-operation in Europe, 1975, p. 10.

9 Booth and Wheeler, The Security Dilemma, pp. 5-8.

10 William Safire, "On language: The Near Abroad," New York Times, 22 May 1994. 
11 Napoleon invaded Russia in 1812, and in 1914, Russia declared war on the German and Austro-Hungarian empires as part of the First World War. Following this, in 1941, Nazi Germany invaded the USSR.

12 Malcolm Fraser, "Ukraine: there's no way out unless the west understands its past mistakes," The Guardian, 3 March 2014.

13 Czechoslovakia broke up into the Czech Republic and Slovakia in 1993. Although Poland does not border contiguous Russia, Poland's northeast frontier borders the Kaliningrad Oblast (formerly the German city of Koenigsberg) that came under Russian control after 1945.

14 "Chechnya profile," $B B C, 18$ March 2014, <http://www.bbc.com/news/ world-europe-18188085>; "Moscow siege leaves dark memories," $B B C$, 16 December 2002, <http://news.bbc.co.uk/2/hi/europe/2565585.stm>

15 "Putin's action-man holiday album," BBC, 5 August 2009, <http://news. bbc.co.uk/2/hi/europe/8185524.stm>

16 Kathrin Hille and Neil Buckley, "Vladimir Putin, strongman of Russia gambling on western weakness," Financial Times, 7 March 2014.

17 "Crimea seen as 'Hitler-style' land grab," $B B C, 7$ March 2014, $<$ http://www.bbc.com/news/world-europe-26488652>; "Hillary Clinton's Putin-Hitler analogy," BBC, 6 May 2014, <http://www.bbc.com/news/ blogs-echochambers-26476643>; and "Prince Charles "compared Russian actions to Nazis'," BBC, 21 May 2014, <http://www.bbc.com/news/worldus-canada-27497899>

18 Grigas, "How Putin carries out power grab."

19 Robert Coalson, "Putin Pledges To Protect All Ethnic Russians Anywhere. So, Where Are They?," Radio Free Europe, 10 April 2014, $<$ http://www.rferl.org/content/russia-ethnic-russification-balticskazakhstan-soviet/25328281.html>

20 "Kellogg-Briand Pact (1928)," United States Statutes at Large, Vol. 46, Pt. 2, p. 2343.

21 Richard Current, "The Stimson Doctrine and the Hoover Doctrine," The American Historical Review, Vol. 59, No. 3, April 1954, pp. 541-542. 22 Zachary Keck, "Russia Expands Naval Presence in Crimea," The Diplomat, 15 May 2014.

23 United Nations, "Article 24," Article 24 of the Vienna Convention on Succession of States in respect of Treaties, Vienna, 1978, p. 12.

24 Article 26 of the Vienna Convention.

25 "Memorandum on Security Assurances in connection with Ukraine's accession to the Treaty on the NPT," 19 December 1994, <https://www. msz.gov.pl/en/p/wiedenobwe_at_s_en/news/memorandum_on_security_ assurances_in_connection_with_ukraine_s_accession_to_the_treaty_on_ the_npt?printMode $=$ true $>$ 
26 Francis X. Clines, "Upheaval in the East; Gorbachev Warns Estonia On Moves For Independence," New York Times, 5 April 1990.

27 Victor Yushchenko, "Holodomor," The Wall Street Journal, 27 November 2007.

28 Chelsea J. Carter, Laura Smith-Spark and Michael Holmes, "Ukraine PM: Crimea 'was, is and will be an integral part of Ukraine'," CNN, 7 March 2014, <http://edition.cnn.com/2014/03/06/world/europe/ukrainerussia-tensions/>

29 Richard Nixon, "Address to the Nation on the War in Vietnam," 3 November 1969, <http://www.nixonlibrary.gov/forkids/speechesforkids/ silentmajority/silentmajority_transcript.pdf $>$

30 Don Oberdorfer, The Two Koreas: A Contemporary History, New York: Perseus Books, 2001, pp. 13-14.

31 Selig Harrison, Korean Endgame: A Strategy for Reunification and US Disengagement, Princeton: Princeton University Press, 2002, pp. 246-50. 32 "The Poor Man's Nukes," Air Force Magazine, Vol. 81, No. 3, 1998. 33 Eve Conant, "Ethnic Russians: Pretext for Putin's Ukraine Invasion?," National Geographic Society, 1 May 2014.

34 Thomas J Christensen, "The Contemporary Security Dilemma: Deterring a Taiwan Conflict," The Washington Quarterly, Autumn 2002, pp. 8-10. 